\title{
Efficient synthesis of kainic acid analogues
}

\author{
Lucia Tamborini,* Federica Mastronardi, Gregorio Cullia, Roberta Ettari, \\ and Carlo De Micheli
}

Dipartimento di Scienze Farmaceutiche, Università degli Studi di Milano, Via Mangiagalli 25, 20133 Milano, Italy

E-mail: lucia.tamborini@unimi.it

\begin{abstract}
The present paper deals with an improved synthesis of two molecular hybrids of AMPA and KA, compounds CIP-A and CIP-B, and their transformation into CIOP-A and CIOP-B, the corresponding amido derivatives. Exploiting the continuous-flow technology, a significant improvement in the synthesis of the glutamate agonists CIP-A and CIP-B was accomplished, in terms of overall yield, time, and excess of ethyl chlorooximinoacetate. Moreover, we find out the HPLC conditions suitable to separate, at a preparative level, the three intermediates formed in the 1,3-dipolar cycloaddition step.
\end{abstract}

Keywords: 1,3-Dipolar cycloaddition, flow chemistry, preparative HPLC separation, glutamate receptor ligands, amino acids

\section{Introduction}

The acidic amino acid neurotransmitter L-glutamate (Glu) plays a pivotal role in the excitatory pathways of the mammalian central nervous system (CNS). ${ }^{1,2}$ Once released from the presynaptic neurons into the glutamatergic synaptic cleft, Glu activates two main classes of receptors: G-protein-coupled metabotropic Glu receptors (mGluRs) and ligand-gated ionotropic Glu receptors (iGluRs). The iGluRs are the major players in the fast neuronal signaling and represent a potential therapeutic target for the treatment of a number of neurological and psychiatric disorders, i.e. chronic pain, stroke, epilepsy, drug addiction, schizophrenia, and Alzheimer, Huntington and Parkinson diseases. ${ }^{3-7}$

On the basis of the agonist selectivity, iGluRs have been subclassified into $N$-methyl-Daspartate (NMDA) receptors, 2-amino-3-(3-hydroxy-5-methyl-4-isoxazolyl)propionate (AMPA) receptors, and kainate (KA) receptors. ${ }^{1,2}$ The functional ion channel is composed of four subunits, which can assemble either homomerically or heteromerically. A total of seven NMDA 
subunits (GluN1, GluN2A-D and GluN3A-B), four AMPA subunits (GluA1-4), and five KA subunits (GluK1-5) have been cloned and characterized. ${ }^{2}$

In the past, we have designed compounds CIP-A, CIP-B, HIP-A, and HIP-B (Figure 1) as molecular hybrids of AMPA and KA. In red is highlighted the structural part representing the skeleton of glutamic acid, homoglutamic acid (CIP-B) or aspartic acid (HIP-A) ${ }^{8-11}$

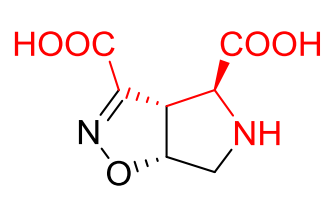

CIP-A

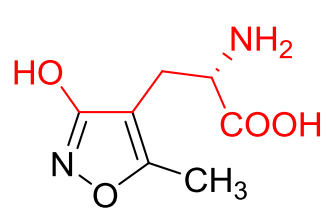

(S)-AMPA

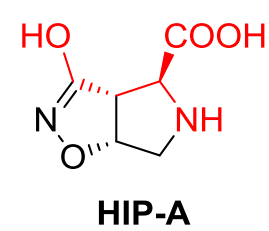

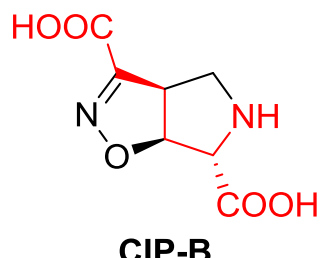

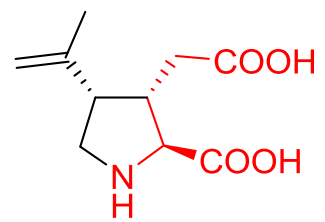

KA

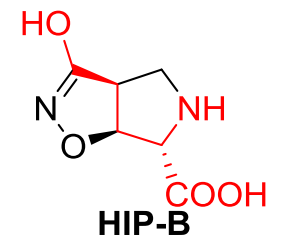

Figure 1. Structure of $(S)$-AMPA, KA and their molecular hybrids.

As expected, compound CIP-A turned out to be a potent agonist at both AMPA and KA receptors without any activity at NMDA receptors. ${ }^{8,9}$ The eutomer of CIP-A was characterized by the $\mathrm{S}$ configuration at the amino acidic stereogenic center. On the contrary, both HIP-A and HIP-B turned out to be inactive at metabotropic and ionotropic glutamate receptors whereas they were provided with an interesting inhibitory activity at glutamate transporters. ${ }^{12-15}$ In parallel, we carried out a detailed investigation on the structure-activity relationships of these rigidified aspartate-glutamate analogues to find out selective iGluR ligands. The bicyclic structure was either simplified into monocyclic derivatives or was conserved and the chain connecting the amino acidic moiety and the distal acidic group was elongated or shortened. In such a way we were able to modulate their pharmacological profile on passing from agonists to antagonists or to generate a remarkable selectivity for one of the three iGluRs. ${ }^{16-30}$ In the planned derivatives, we always preserved the aminoacid moiety because the X-ray structural analyses of the iGluRs bilobular ligand-binding core in complex with agonists or antagonists evidenced the crucial role played by such a group. ${ }^{31}$ In a recent paper, ${ }^{32}$ it was described a series of derivatives generated by the incorporation of the structural elements of both kainic acid and neodysiherbaine A (neoDH), two naturally occurring pro-convulsant agents. Surprisingly, some of them, e.g. 
derivative IKM-159, are characterized by the presence in their structure of the $\alpha$-carboxylate amido group (Figure 2) and are provided with a potent AMPA-selective antagonistic activity. ${ }^{32}$ On this ground, we designed the corresponding analogues of CIP-A and CIP-B in order to test their pharmacological profile and their selectivity versus AMPA receptor subtypes.

The present paper deals with an improved synthesis of CIP-A and CIP-B and their transformation into CIOP-A and CIOP-B, the corresponding amido derivatives (Figure 2).

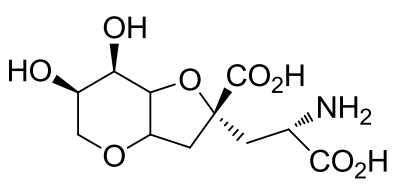

neoDH

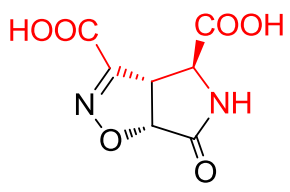

CIOP-A

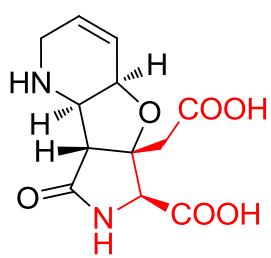

IKM-159

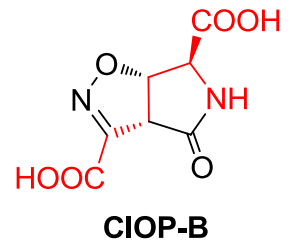

Figure 2. Structures of model and target compounds.

\section{Results and Discussion}

According to a literature report, ${ }^{9}$ the synthesis of CIP-A and CIP-B, as pure enantiomers, has been accomplished as depicted in Scheme 1.

The major drawbacks associated to the described procedure ${ }^{9}$ are: i) the low reactivity of dipolarophile $\mathbf{1}$ and ii) the failure to separate cycloadduct $\mathbf{3}$ from $\mathbf{4}$ by column chromatography. For such a reason, the mixture was transformed into the corresponding secondary amines $\mathbf{5}$ and $\mathbf{6}$ which were separated by column chromatography and then reconverted into the $N$-Boc derivatives $\mathbf{3}$ and $\mathbf{4}$, respectively.

In order to overcome the first drawback, we decided to investigate the feasibility of the cycloaddition reaction with the flow technology by using a procedure previously applied to similar pericyclic reactions. ${ }^{33,34}$ As shown in scheme 2, an ethyl acetate solution of $\mathrm{N}$-Boc-3,4dehydro-L-proline methyl ester $\mathbf{1}$, prepared under flow conditions as previously reported, ${ }^{35}$ and ethyl chlorooximinoacetate were mixed and delivered to a glass column filled with solid $\mathrm{K}_{2} \mathrm{CO}_{3}$ heated at $90{ }^{\circ} \mathrm{C}$. The desired cycloadducts were obtained in good yield (70\%) in only $10 \mathrm{~min}$ and a slight excess of chloroxime. This result represents a significant improvement over the above described conventional methodology because the reaction time was considerably reduced (from 6 days to $10 \mathrm{~min}$ ) and the overall yield improved (from 56\% to $70 \%$ ). 


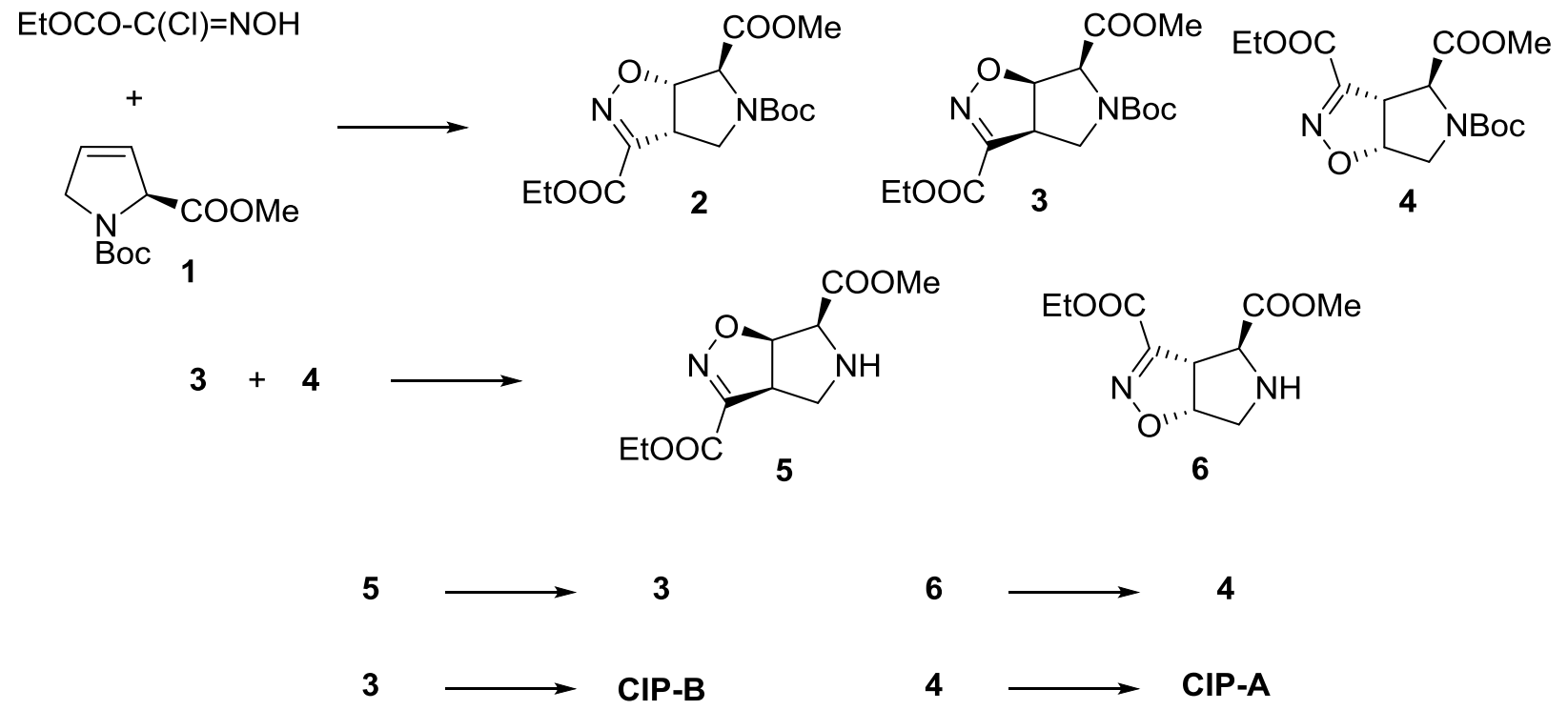

Scheme 1. Previously reported synthesis of CIP-A and CIP-B. ${ }^{9}$

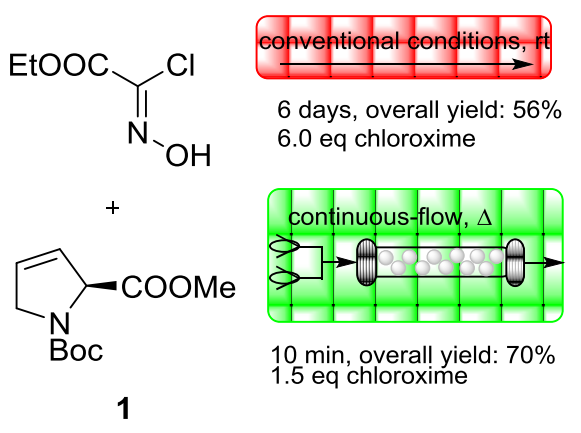

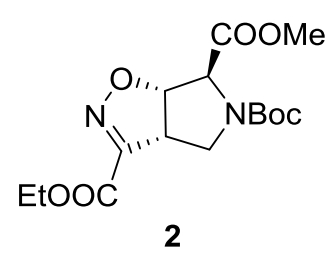

Preparative HPLC separation: 2:3:4 = 40:14:46

Scheme 2. The cycloaddition reaction in a continuous flow reactor.

The second drawback, due to the incapability to split with a silica gel column chromatography the mixture of cycloadducts $\mathbf{2}, \mathbf{3}$, and $\mathbf{4}$, was explored by making use of a preparative HPLC. After a substantial number of attempts, we found out the conditions suitable to separate the cycloadducts at a preparative level. An excellent separation (see experimental section) was obtained with the amylose tris-(5-chloro-2-methyl-phenyl-carbamate) stationary phase, allowing us to collect a substantial amount of each stereoisomer. The cycloaddition step yielded intermediates $2: 3: 4$ in the ratio 40:14:46.

Cycloadducts $\mathbf{2}$ and $\mathbf{4}$ were then oxidized with a catalytic amount of hydrated ruthenium (IV) oxide and a $10 \%$ aqueous solution of sodium periodate in a biphasic system water/ethyl acetate to give intermediate 7 and $\mathbf{8}$, respectively. Their stereochemistry was secured by ${ }^{1} \mathrm{H} \mathrm{NMR}$. As a matter of fact, derivative 7 shows proton $3 \mathrm{a}$ at 4.53 as a doublet $(J=9.3 \mathrm{~Hz})$, whereas the same proton in derivative 8 resonates at 4.10 as a doublet of doublet $(J=1.3,10.4 \mathrm{~Hz})$. Intermediates 7 
and 8 were treated with an aqueous $6 \mathrm{~N} \mathrm{HCl}$ solution, according to the procedure described for the synthesis of IKM 159 (Scheme 3). ${ }^{36}$

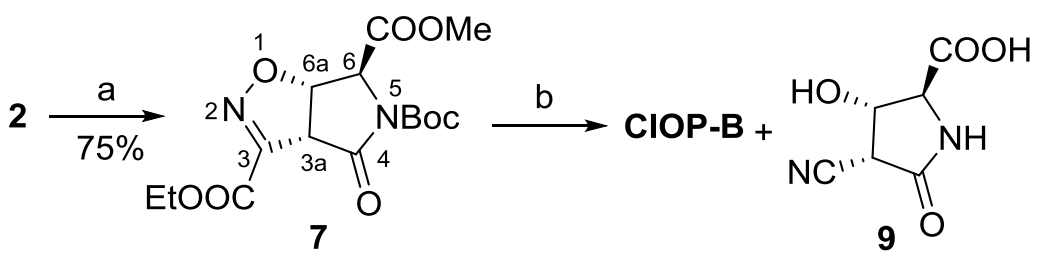

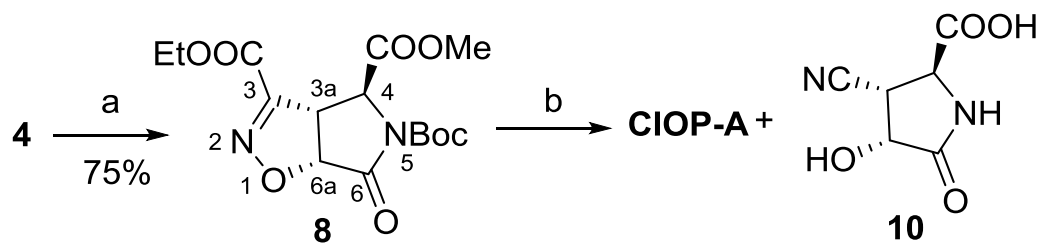

Scheme 3. Reagents and conditions: $\mathrm{a}: \mathrm{RuO}_{2} * \mathrm{H}_{2} \mathrm{O}, \mathrm{NaIO}_{4}, \mathrm{H}_{2} \mathrm{O} / \mathrm{AcOEt}$; $\mathrm{b}: \mathrm{HCl} 6 \mathrm{~N}, \Delta$.

Unfortunately, we obtained a 1:2 unsplitable mixture of CIOP-B and 9 or CIOP-A and 10. The hydroxynitrile side-products $\mathbf{9}$ and $\mathbf{1 0}$ derived from the low stability of the isoxazoline ring under aqueous acidic conditions. Therefore, we decided to remove the nitrogen protecting group by treating derivatives $\mathbf{7}$ and $\mathbf{8}$ with an excess of trifluoroacetic acid; amides $\mathbf{1 1}$ and $\mathbf{1 2}$ were obtained in good yield (Scheme 4).<smiles>CCOC(=O)C1NC(=O)[C@@H]2C(C(=O)OC)=NO[C@@H]12</smiles><smiles>CCOC(=O)C1=NO[C@H]2C(=O)N[C@@H](C(=O)OCC(C)C)[C@H]12</smiles>

Scheme 4. Reagents and conditions: a: $30 \% \mathrm{TFA} / \mathrm{CH}_{2} \mathrm{Cl}_{2} ;$ b: $\mathrm{K}_{2} \mathrm{CO}_{3}, \mathrm{H}_{2} \mathrm{O}$.

Final compounds CIOP-B and CIOP-A were obtained, in quantitative yield, through the alkaline hydrolysis of the two ester groups under mild conditions, i.e. 2.2 equivalent of an aqueous $\mathrm{K}_{2} \mathrm{CO}_{3}$ solution. Using harsher basic condition, such as an aqueous $\mathrm{NaOH}$ solution, we observed a substantial degradation of the cycloadducts. 


\section{Conclusions}

We have accomplished a significant improvement in the synthesis of glutamate agonists CIP-A and CIP-B in terms of overall yield, time, and excess of ethyl chlorooximinoacetate. Furthermore, we find out the HPLC conditions suitable to separate, at a preparative level, the three cycloadducts $\mathbf{2}, \mathbf{3}$, and $\mathbf{4}$. In such a way, we avoided the lengthy procedure based on the transformation of the unsplittable mixture of derivative $\mathbf{3}$ and $\mathbf{4}$ into the corresponding secondary amines 5 and 6, their separation by a silica gel column chromatography and then their reconvertion into the $N$-Boc derivatives $\mathbf{3}$ and $\mathbf{4}$. Furthermore, the two regioisomers $\mathbf{2}$ and $\mathbf{4}$ were transformed into final derivatives CIOP-B and CIOP-A, respectively, via an oxidation step, removal of the $\mathrm{N}$-Boc protecting group and a careful hydrolysis of the two ester groups. The biological results of the novel derivatives CIOP-A and CIOP-B will challenge the involvement of the amino acid moiety in determining the binding to the active site of the ionotropic glutamate receptors. These data will be reported in due course.

\section{Experimental Section}

General. All reagents were purchased from Sigma. ${ }^{1} \mathrm{H}$ NMR and ${ }^{13} \mathrm{C}$ NMR spectra were recorded with a Varian Mercury $300(300 \mathrm{MHz})$ spectrometer. Chemical shifts $(\delta)$ are expressed in ppm, and coupling constants $(J)$ are expressed in Hz. Rotary power determinations were carried out using a Jasco P-1010 spectropolarimeter, coupled with a Haake N3-B thermostat. TLC analyses were performed on commercial silica gel $60 \mathrm{~F}_{254}$ aluminum sheets; spots were further evidenced by spraying with a dilute alkaline potassium permanganate solution or ninhydrin. MS analyses were performed on a Varian 320-MS triple quadrupole mass spectrometer with ESI source. Microanalyses $(\mathrm{C}, \mathrm{H}, \mathrm{N})$ of new compounds were within $\pm 0.4 \%$ of theoretical values. HPLC analyses were performed with a Jasco PU-980 pump equipped with a UV-vis detector Jasco UV-975 (wavelength: $220 \mathrm{~nm}$ ) and Phenomenex Lux Amylose-2 column $(4.6 \times 150 \mathrm{~mm})$. Preparative HPLC was performed with a 1525 Extended Flow Binary HPLC Pump, equipped with a Waters 2489 UV-vis detector and a Phenomenex Lux Amylose-2 column $(21.2 \times 250 \mathrm{~mm})$ at a flow rate of $15 \mathrm{~mL} / \mathrm{min}$. The continuous-flow cycloaddition was performed using a R2+/R4 flow reactor, commercially available from Vapourtec equipped with Omnifit glass column.

$(3 \mathrm{a} R, 6 R, 6 \mathrm{a} S)-5$-tert-Butyl 3-ethyl 6-methyl 3a,4,6,6a-tetrahydropyrrolo[3,4- $d$ ]isoxazole3,5,6-tricarboxylate (2), (3aS,6S,6aR)-5-tert-butyl 3-ethyl 6-methyl 3a,4,6,6atetrahydropyrrolo[3,4-d]isoxazole-3,5,6-tricarboxylate $(3)$, and $(3 \mathrm{a} S, 4 S, 6 \mathrm{a} R)$-5-tert-butyl 3ethyl 4-methyl 3a,4,6,6a-tetrahydropyrrolo[3,4-d]isoxazole-3,4,5-tricarboxylate (4). A 0.25 M solution of methyl $N$-Boc-3,4-dehydro-L-proline methyl ester (1.0 mmol) in EtOAc (4 mL) and a $0.37 \mathrm{M}$ solution of ethyl chlorooximinoacetate $(1.5 \mathrm{mmol})$ in EtOAc $(4 \mathrm{~mL})$ were 
prepared. The two reactant streams were mixed using a simple T-piece and delivered to a glass column (6.6 mm i.d. $\times 100 \mathrm{~mm}$ length) filled with $\mathrm{K}_{2} \mathrm{CO}_{3}(4.0 \mathrm{mmol}, 540 \mathrm{mg})$ heated at $90{ }^{\circ} \mathrm{C}$ at

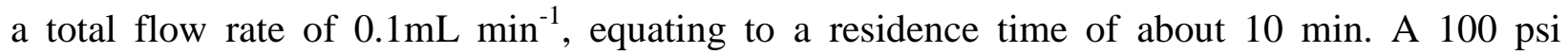
backpressure regulator was applied to the system. The solvent was evaporated, and the crude material was purified by silica gel column chromatography (cyclohexane-EtOAc 7:3) to yield the mixture of cycloadducts 2, 3, 4 in $70 \%$ overall yield. Analytical HPLC condition: wavelength, $220 \mathrm{~nm}$; eluent, $n$-hexane-2-propanol (8:2). Retention times: 4, 7.51 min.; 2, 13.01 min.; 3, 16.77 min.

(3aR,6S,6aS)-5-tert-Butyl 3-ethyl 6-methyl 3a,4,6,6a-tetrahydro-4-oxopyrrolo[3,4- $d$ ]isoxazole-3,5,6-tricarboxylate (7). To a magnetically stirred $10 \%$ aqueous solution of $\mathrm{NaIO}_{4}$ $(2.38 \mathrm{~g}, 11.4 \mathrm{mmol})$ was added $\mathrm{RuO}_{2} * \mathrm{H}_{2} \mathrm{O}(21 \mathrm{mg})$. The mixture was immediately poured into a solution of cycloadduct 2 (960 mg, $2.84 \mathrm{mmol})$ in EtOAc $(27 \mathrm{~mL})$ and the resulting suspension was vigorously stirred at room temperature for $24 \mathrm{~h}$. The black solid was removed by filtration under vacuum through a short Celite pad, and the organic layer was separated and treated with 2propanol $(2 \mathrm{~mL})$. The organic solution was dried over anhydrous $\mathrm{Na}_{2} \mathrm{SO}_{4}$, the solvent removed under vacuum, and the residue was column chromatographed (cyclohexane-EtOAc 7:3) to give $130 \mathrm{mg}$ of the desired product 7 and $560 \mathrm{mg}$ of the unreacted starting material 2 . Yield based on recovered starting material: $75 \%$. Colorless oil; $[\alpha]_{\mathrm{D}}{ }^{20}-27.3$ (c $\left.0.56, \mathrm{CHCl}_{3}\right) ; R_{f} 0.25$ (Cyclohexane-EtOAc, 7:3). ${ }^{1} \mathrm{H}$ NMR (300 MHz, $\left.\mathrm{CDCl}_{3}\right): \delta 1.38(\mathrm{t}, 3 \mathrm{H}, J$ 7.0); 1.45 (s, 9H); 3.82 $(\mathrm{s}, 3 \mathrm{H}) ; 4.36(\mathrm{q}, 2 \mathrm{H}, J 7.0) ; 4.53(\mathrm{~d}, 1 \mathrm{H}, J 9.3) ; 4.91(\mathrm{~s}, 1 \mathrm{H} ;) ; 5.23(\mathrm{~d}, 1 \mathrm{H}, J 9.3) .{ }^{13} \mathrm{C}$ NMR $(75$ $\left.\mathrm{MHz}, \mathrm{CDCl}_{3}\right): \delta 14.2,28.0,53.6,55.2,63.1,64.7,82.0,85.4,148.7,149.3,158.5,165.0,168.8$. MS: $357.1[\mathrm{M}+\mathrm{H}]^{+}$. Anal. Calcd for $\mathrm{C}_{15} \mathrm{H}_{20} \mathrm{~N}_{2} \mathrm{O}_{8}: \mathrm{C}, 50.24 ; \mathrm{H}, 5.79 ; \mathrm{N}, 7.86$. Found: C 50.37, $\mathrm{H}$ 5.76, N 7.75.

\section{(3aS,4S,6aR)-5-tert-Butyl 3-ethyl 4-methyl 3a,4,6,6a-tetrahydro-6-oxopyrrolo[3,4-d]-} isoxazole-3,4,5-tricarboxylate (8). To a magnetically stirred $10 \%$ aqueous solution of $\mathrm{NaIO}_{4}$ ( $2.43 \mathrm{~g}, 11.4 \mathrm{mmol}$ ) was added $\mathrm{RuO}_{2} * \mathrm{H}_{2} \mathrm{O}(21 \mathrm{mg})$. The mixture was immediately poured into a solution of cycloadduct 4 (970 mg, $2.84 \mathrm{mmol})$ in EtOAc $(27 \mathrm{~mL})$ and the resulting suspension was vigorously stirred at room temperature for $24 \mathrm{~h}$. The black solid was removed by filtration under vacuum through a short Celite pad, and the organic layer was separated and treated with 2propanol $(2 \mathrm{~mL})$. The organic solution was dried over anhydrous $\mathrm{Na}_{2} \mathrm{SO}_{4}$, the solvent removed under vacuum, and the residue was column chromatographed (cyclohexane-EtOAc 7:3) to give $140 \mathrm{mg}$ of the desired product 8 and $590 \mathrm{mg}$ of the unreacted starting material 4. Yield based on recovered starting material: $75 \%$. Colorless oil; $[\alpha]_{\mathrm{D}}{ }^{20}-176.0$ (c $\left.0.56, \mathrm{CHCl}_{3}\right) ; R_{f} 0.25$ (Cyclohexane-EtOAc, 7:3). ${ }^{1} \mathrm{H}$ NMR (300 MHz, $\left.\mathrm{CDCl}_{3}\right): \delta 1.38(\mathrm{t}, 3 \mathrm{H}, J 7.0) ; 1.45(\mathrm{~s}, 9 \mathrm{H}) ; 3.82$ (s, 3H); 4.10 (dd, 1H, J 1.3, 10.4); $4.33-4.44$ (m, 2H); 4.90 (d, 1H, J 1.3); 5.37 (d, 1H, J 10.4). ${ }^{13} \mathrm{C} \mathrm{NMR}\left(75 \mathrm{MHz}, \mathrm{CDCl}_{3}\right.$ ): $\delta 14.2,28.0,47.4,53.6,59.8,63.2,83.0,85.5,148.7,150.2,159.3$, 166.8, 170.4. MS: 357.1 [M+H] $]^{+}$. Anal. Calcd for $\mathrm{C}_{15} \mathrm{H}_{20} \mathrm{~N}_{2} \mathrm{O}_{8}$ : C, 50.24; H, 5.79; N, 7.86. Found: C 50.33, H 5.78, N 7.72.

(3aR,6S,6aS)-3-Ethyl 6-methyl 4,5,6,6a-tetrahydro-4-oxo-3a $H$-pyrrolo[3,4- $d]$ isoxazole-3,6dicarboxylate (11). Compound $7(130 \mathrm{mg}, 0.37 \mathrm{mmol})$ was treated with $1 \mathrm{~mL}$ of a $30 \% \mathrm{CH}_{2} \mathrm{Cl}_{2}$ 
solution of trifluoroacetic acid at $0{ }^{\circ} \mathrm{C}$. The solution was stirred at room temperature for $4 \mathrm{~h}$. The volatiles were removed under vacuum and the residue was purified by flash chromatography to yield $65 \mathrm{mg}$ (70\% yield) of the desired product 11 as a colorless oil that was immediately used in the next synthetic step. $R_{f} 0.6$ (EtOAc). ${ }^{1} \mathrm{H}$ NMR $\left(300 \mathrm{MHz}, \mathrm{CDCl}_{3}\right): 1.40$ (t, 3H, J 7.0); 3.82 (s, $3 \mathrm{H}) ; 4.40$ (q, 1H, J 7.0); $4.40(\mathrm{~d}, 1 \mathrm{H}, J 9.3) ; 4.50(\mathrm{~s}, 1 \mathrm{H}) ; 5.60(\mathrm{~d}, 1 \mathrm{H}, J 9.3) ; 6.82(\mathrm{bs}, 1 \mathrm{H}) .{ }^{13} \mathrm{C}$ NMR $\left(75 \mathrm{MHz}, \mathrm{CDCl}_{3}\right): \delta 14.3,53.6,55.3,63.2,64.9,85.4,149.4,163.9,165.0,168.9$. MS: $257.1[\mathrm{M}+\mathrm{H}]^{+}$. Anal. Calcd for $\mathrm{C}_{10} \mathrm{H}_{12} \mathrm{~N}_{2} \mathrm{O}_{6}$ : C, 46.88; H, 4.72; N, 10.93. Found: C 47.00, H $4.53, \mathrm{~N} 10.80$.

(3aS,4S,6aR)-3-Ethyl 4-methyl 4,5,6,6a-tetrahydro-6-oxo-3a $H$-pyrrolo[3,4- $d]$ isoxazole-3,4dicarboxylate (12). Compound 8 (140 mg, $0.40 \mathrm{mmol})$ was treated with $1 \mathrm{~mL}$ of a $30 \% \mathrm{CH}_{2} \mathrm{Cl}_{2}$ solution of trifluoroacetic acid at $0{ }^{\circ} \mathrm{C}$. The solution was stirred at room temperature for $4 \mathrm{~h}$. The volatiles were removed under vacuum and the residue was purified by flash chromatography to yield $75 \mathrm{mg}$ (75\% yield) of the desired product 12 as a colorless oil that was immediately used in the next synthetic step. $R_{f} 0.6$ (EtOAc). ${ }^{1} \mathrm{H}$ NMR (300 $\mathrm{MHz}, \mathrm{CDCl}_{3}$ ): $\delta 1.40$ (t, 3H, $J 7.3$ ); 3.82 (s, 3H); 4.35-4.44 (m, 2H); 4.46 (dd, 1H, J 1.2, 10.2); 4.55 (d, 1H, J 1.2); 5.32 (d, 1H, J 10.2); 7.50 (bs, $1 \mathrm{H}) .{ }^{13} \mathrm{C}$ NMR $\left(75 \mathrm{MHz}, \mathrm{CDCl}_{3}\right): \delta 14.1,47.5,53.7,59.7,63.3,85.6,150.3,163.5$, 166.9, 170.5. MS: 257.1 [M+H] $]^{+}$. Anal. Calcd for $\mathrm{C}_{10} \mathrm{H}_{12} \mathrm{~N}_{2} \mathrm{O}_{6}: \mathrm{C}, 46.88 ; \mathrm{H}, 4.72 ; \mathrm{N}, 10.93$. Found: C 47.08, H 4.50, N 10.78.

$(3 \mathrm{a} R, 6 \mathrm{~S}, 6 \mathrm{a} S)-4,5,6,6 \mathrm{a}-\mathrm{Tetrahydro}-4-0 \times 0-3 \mathrm{a} H$-pyrrolo[3,4- $d]$ isoxazole-3,6-dicarboxylic acid (CIOP-B). Compound 9 (60 mg, $0.23 \mathrm{mmol}$ ) was suspended in bi-distilled water and $\mathrm{K}_{2} \mathrm{CO}_{3}$ (71 $\mathrm{mg}, 0.52$ ) was added. The reaction mixture was stirred at room temperature for $16 \mathrm{~h}$. The mixture was made acidic $(\mathrm{pH} 2)$ with $1 \mathrm{~N}$ aqueous $\mathrm{HCl}$ and the solvent was removed under reduced pressure. The residue was taken up with acetone and filtered. The solvent was removed under reduced pressure to give CIOP-B $(50 \mathrm{mg}, 0.23 \mathrm{mmol})$ as a white solid. $[\alpha]_{\mathrm{D}}{ }^{20}+2.0(c 0.41$, $\mathrm{H}_{2} \mathrm{O}$ ). ${ }^{1} \mathrm{H}$ NMR $\left(300 \mathrm{MHz}, \mathrm{D}_{2} \mathrm{O}\right): \delta 4.38(\mathrm{~d}, 1 \mathrm{H}, J 1.1) ; 4.42(\mathrm{~d}, 1 \mathrm{H}, J$ 9.1); 5.47 (dd, $1 \mathrm{H}, J$ 1.1, 9.1). ${ }^{13} \mathrm{C}$ NMR $\left(75 \mathrm{MHz}, \mathrm{D}_{2} \mathrm{O}\right): \delta 55.5,63.7,86.7,153.1,163.9,173.1,174.4 . \mathrm{MS}: 212.9$ $[\mathrm{M}-\mathrm{H}]^{-}$. Anal. Calcd for $\mathrm{C}_{7} \mathrm{H}_{6} \mathrm{~N}_{2} \mathrm{O}_{6}: \mathrm{C}, 39.26 ; \mathrm{H}, 2.82 ; \mathrm{N}, 13.08$. Found: C, 39.06; H, 2.87; N, 13.01.

$(3 \mathrm{a} S, 4 S, 6 \mathrm{a} R)-4,5,6,6 \mathrm{a}-T e t r a h y d r o-6-0 x 0-3 \mathrm{a} H$-pyrrolo[3,4- $d]$ isoxazole-3,4-dicarboxylic acid (CIOP-A). Compound 10 (70 mg, $0.27 \mathrm{mmol}$ ) was suspended in bi-distilled water and $\mathrm{K}_{2} \mathrm{CO}_{3}$ (83 $\mathrm{mg}, 0.60)$ was added. The reaction mixture was stirred at room temperature for $16 \mathrm{~h}$. The mixture was made acidic $(\mathrm{pH} 2)$ with $1 \mathrm{~N}$ aqueous $\mathrm{HCl}$ and the solvent was removed under reduced pressure. The residue was taken up with acetone and filtered. The solvent was removed under reduced pressure to give compound CIOP-A $(58 \mathrm{mg}, 0.27 \mathrm{mmol})$ as a white solid. $[\alpha]_{\mathrm{D}}{ }^{20}-$ 189.8 ( $c$ 0.42, $\left.\mathrm{H}_{2} \mathrm{O}\right) .{ }^{1} \mathrm{H}$ NMR $\left(300 \mathrm{MHz}, \mathrm{D}_{2} \mathrm{O}\right): \delta 4.42$ (dd, $\left.1 \mathrm{H}, J 1.5,9.7\right) ; 4.53$ (d, 1H, $J$ 1.5); $5.33\left(\mathrm{~d}, 1 \mathrm{H}, J\right.$ 9.7). ${ }^{13} \mathrm{C}$ NMR $\left(75 \mathrm{MHz}, \mathrm{D}_{2} \mathrm{O}\right): \delta 51.5,58.0,82.5,155.1,163.2,174.1,174.6$. MS: $212.8[\mathrm{M}-\mathrm{H}]^{-}$. Anal. Calcd for $\mathrm{C}_{7} \mathrm{H}_{6} \mathrm{~N}_{2} \mathrm{O}_{6}: \mathrm{C}, 39.26 ; \mathrm{H}, 2.82 ; \mathrm{N}, 13.08$. Found: C, 39.64; H, 2.95; N, 12.86 . 


\section{Acknowledgements}

The financial support to the present research by the Italian Ministry of Education and Research (MIUR - Rome) is acknowledged.

\section{References}

1. Riedel, G.; Platt, B.; Micheau, J. Behav. Brain Res. 2003, 140, 1-47. http://dx.doi.org/10.1016/S0166-4328(02)00272-3

2. Bräuner-Osborne, H.; Egebjerg, J.; Nielsen, E. Ø.; Madsen, U.; Krogsgaard-Larsen, P. J. Med. Chem. 2000, 43, 2609-2645. http://dx.doi.org/10.1021/jm000007r

3. O'Neill, M. J.; Bleakman, D.; Zimmerman, D. M.; Nisenbaum, E. S. Curr. Drug Targets: CNS Neurol. Disord. 2004, 3, 181-194. http://dx.doi.org/10.2174/1568007043337508

4. Francis, P.T. CNS Spectrums 2005, 10, 6-9. PMid:16273023

5. Stawski, P.; Janovjak, H.; Trauner, D. Bioorg. Med. Chem. 2010, 18, 7759-7772. http://dx.doi.org/10.1016/j.bmc.2010.09.012

6. Conti, P.; De Amici, M.; De Micheli, C. Mini-Rev. Med. Chem. 2002, 2, 177-184. http://dx.doi.org/10.2174/1389557024605456 PMid:12370078

7. Cosman, K.M.; Boyle, L.L.; Porsteinsson, A.P. Expert Opin. Pharmacother. 2007, 8, $203-$ 214.

http://dx.doi.org/10.1517/14656566.8.2.203

PMid:17257090

8. Conti, P.; De Amici, M.; De Sarro, G.; Stensbol, T.B.; Bräuner-Osborne, H.; Madsen, U.; De Micheli, C. J. Med. Chem. 1998, 41, 3759-3762.

http://dx.doi.org/10.1021/jm9803020

9. Conti, P.; De Amici, M.; De Sarro, G.; Rizzo, M.; Stenbøl, T.B.; Bräuner-Osborne, H.; Madsen, U.; Toma, L.; De Micheli, C. J. Med. Chem. 1999, 42, 4099-4107. http://dx.doi.org/10.1021/jm991081g

10. Conti, P.; Dallanoce, C.; De Amici, N.; De Micheli, C.; Fruttero, R. Tetrahedron 1999, 55, 5623-5634.

http://dx.doi.org/10.1016/S0040-4020(99)00228-8

11. Conti, P.; Roda, G.; Barberis Negra, F. F. TetrahedronAsymmetry 2001,12, 1363-1367. http://dx.doi.org/10.1016/S0957-4166(01)00225-7 
12. Funicello, M.; Conti, P.; De Amici, M.; De Micheli, C.; Mennini, T.; Gobbi, M. Mol. Pharmacol. 2004, 66, 522-529.

PMid:15322243

13. Pinto, A.; Conti, P.; De Amici, M.; Tamborini, L.; Grazioso, G.; Colleoni, S.; Mennini, T.; Gobbi, M.; De Micheli C. Tetrahedron: Asymmetry 2008, 19, 867-875. http://dx.doi.org/10.1016/j.tetasy.2008.03.001

14. Colleoni, S.; Jensen, A.A.; Landucci, E.; Fumagalli, E.; Conti, P.; Pinto, A.; De Amici, M.; Pellegrini-Giampietro, D.E.; De Micheli, C.; Mennini, T.; Gobbi, M. J. Pharmacol. Exp. Ther. 2008, 326, 646-656. http://dx.doi.org/10.1124/jpet.107.135251

15. Callender, R.; Gameiro, A.; Pinto, A.; De Micheli, C.; Grewer, C. Biochemistry 2012, 51, 5486-5495. http://dx.doi.org/10.1021/bi3006048

16. Conti, P.; De Amici, M.; Joppolo di Ventimiglia, S.; Stensbøl, T.B.; Madsen, U.; BräunerOsborne, H.; Russo, E.; De Sarro, G.; Bruno, G.; De Micheli, C. J. Med. Chem. 2003, 46,3102-3108. http://dx.doi.org/10.1021/jm0308085

17. Roda, G.; Conti, P.; De Amici, M.; He, J.; Polavarapu, P. L.; De Micheli, C. Tetrahedron: Asymmetry 2004, 15, 3079-3090. http://dx.doi.org/10.1016/j.tetasy.2004.07.037

18. Conti, P.; De Amici, M.; Grazioso, C.; Roda, G.; Barberis Negra, F.; Nielsen, T.; Stensbøl, T.B.; Madsen, U.; Bräuner-Osborne, H.; Frydenvang, K.; De Sarro, G.; Toma, L.; De Micheli, C. J. Med. Chem. 2004, 47, 6740-6748. http://dx.doi.org/10.1021/jm049409f

19. Conti, P.; De Amici, M.; Grazioso, C.; Pinto, A.; Roda, G.; Stensbol, T.B.; Madsen, U.; Brauner-Osborne, H.; Pellegrini-Giampietro, D.E.; Acher, F.C.; De Micheli, C. J. Med. Chem. 2005, 48, 6315-6325. http://dx.doi.org/10.1021/jm0504499

20. Conti, P.; Pinto, A.; Roda, G.; Tamborini, L.; Arosio, D.; De Micheli, C. Synthesis 2007, $2145-214$.

http://dx.doi.org/10.1055/s-2007-983750

21. Conti, P.; Pinto, A.; Tamborini, L.; Rizzo, V.; De Micheli, C. Tetrahedron 2007, 63, 55545560. http://dx.doi.org/10.1016/j.tet.2007.04.027

22. Conti, P.; Caligiuri, A.; Pinto, A.; Roda, G.; Tamborini, L.; Nielsen, B.; Madsen, U.; Frydenvang, K.; Colombo, A.; De Micheli, C. Eur. J. Med. Chem. 2007, 42, 1059-1068. http://dx.doi.org/10.1016/j.ejmech.2007.01.013

23. Conti, P.; De Amici, M.; Roda, G.; Pinto, A.; Tamborini, L.; Madsen, U.; Nielsen, B.; Bräuner-Osborne, H.; De Micheli, C. Tetrahedron 2007, 63, 2249-2256. http://dx.doi.org/10.1016/j.tet.2006.12.066 
24. Conti, P.; Pinto, A.; Tamborini, L.; Grazioso, C.; De Sarro, G.; Bräuner-Osborne, H.; Szabo, G.; GáborHársing, L.; De Micheli, C. ChemMedChem 2007, 2, 1639-1647. http://dx.doi.org/10.1002/cmdc.200700118

25. Conti, P.; Joppolo di Ventimiglia, S.; Pinto, A.; Tamborini, L.; Menniti, F.S.; Lazzaro, J.T.; De Micheli, C. Chem. Biodivers. 2008, 5, 657-663. http://dx.doi.org/10.1002/cbdv.200890061

26. Pinto, A.; Conti, P.; De Amici, M.; Tamborini, L.; Madsen, U.; Nielsen, B.; Christesen, T.; Bräuner-Osborne, H.; De Micheli, C. J. Med. Chem. 2008, 51, 2311 - 2315. http://dx.doi.org/10.1021/jm701394a

27. Carrea, G.; De Amici, M.; De Micheli, C.; Liverani, P.; Carnielli, M.; Riva, S. Tetrahedron: Asymmetry 1993, 4, 1063-1072. http://dx.doi.org/10.1016/S0957-4166(00)80155-X

28. Conti, P.; Pinto, A.; Tamborini, L.; Madsen, U.; Nielsen, B.; Bräuner-Osborne, H.; Hansen, K.B.; Landucci, E.; Pellegrini-Giampietro, D.E.; De Sarro, G.; Di Paola, E.D.; De Micheli, C. ChemMedChem 2010, 5, 1465-1475. http://dx.doi.org/10.1002/cmdc.201000184

29. Pinto, A.; Conti, P.; Grazioso, C.; Tamborini, L.; Madsen, U.; Nielsen, B.; De Micheli, C. Eur. J. Med. Chem. 2011, 46, 787-793 http://dx.doi.org/10.1016/j.ejmech.2010.12.020

30. Tamborini, L.; Pinto, A., Conti, P.; Gallanti, M.; Iannuzzi, M. C.; Lo Presti, L.; De Micheli, C. Synthesis 2011, 1255-1260 http://dx.doi.org/10.1055/s-0030-1258477

31. Hogner, A.; Greenwood, J. R.; Liljefors, T.; Lunn, M.-L.; Egebjerg, J.; Larsen, I. K.; Gouaux, E.; Kastrup, J. S. J. Med. Chem. 2003, 46, 214-221. http://dx.doi.org/10.1021/jm020989v

32. Gill, M.B.; Frausto, S.; Ikoma, M.; Oikawa, M.; Sakai, R.; Swanson, G.T.; Br. J. Pharmacol. 2010, 160, 1417-1429. http://dx.doi.org/10.1111/j.1476-5381.2010.00784.x

33. Castellano, S.; Tamborini, L.; Viviano, M.; Pinto, A.; Sbardella, G.; Conti, P. J. Org. Chem. 2010, 75, 7439-7442. http://dx.doi.org/10.1021/jo1014323

34. Castellano, S.; Kuck, D.; Viviano, M.; Yoo, J.; Lopez-Vallejo, F.; Conti, P.; Tamborini, L.; Pinto, A.; Medina-Franco, J. L.; Sbardella, G. J. Med. Chem. 2011, 54, 7663-7677. http://dx.doi.org/10.1021/jm2010404

35. Tamborini, L.; Conti, P.; Pinto, A.; De Micheli, C. Tetrahedron: Asymmetry 2010, 21, 222 225. http://dx.doi.org/10.1016/j.tetasy.2009.12.023

36. Oikawa, M.; Ikoma, M.; Sasaki, M.; Gill, M. B.; Swanson, G. T.; Shimamoto, K.; Sakai R. Bioorg. Med. Chem. 2010, 18, 3795-3804 http://dx.doi.org/10.1016/j.bmc.2010.04.044 